\title{
Carbon utilization profile of a thermophilic fungus, Thermomyces lanuginosus using phenotypic microarray
}

\author{
Nokuthula Peace Mchunu ${ }^{1,2 *}$, Kugen Permaul ${ }^{1}$, Maqsudul Alam ${ }^{2,3}$, Suren Singh $^{1}$ \\ ${ }^{1}$ Department of Biotechnology and Food Technology, Durban University of Technology, Durban, South Africa \\ ${ }^{2}$ Centre for Chemical Biology, University Sains Malaysia, Bayan Lepas, Penang, Malaysia \\ ${ }^{3}$ Advanced Studies in Genomics, Proteomics and Bioinformatics, University of Hawaii, Honolulu, USA \\ Email: nokuthula@dut.ac.za
}

Received 29 June 2013; revised 30 July 2013; accepted 26 August 2013

Copyright (C) 2013 Nokuthula Peace Mchunu et al. This is an open access article distributed under the Creative Commons Attribution License, which permits unrestricted use, distribution, and reproduction in any medium, provided the original work is properly cited.

\begin{abstract}
The thermophilic filamentous fungus, Thermomyces lanuginosus produces the largest amount of xylanase reported. In addition to this, it expresses large amount of other enzymes that have been used industrially or have academic interest. Thus, this fungus has a potential to be applied for biomass conversion to produce biofuel or other applications. In this study, the Biolog system was used to characterize the utilisation and growth of $T$. lanuginosus on 95 carbon sources. The carbohydrates based compounds, both single sugars and oligosaccharide, showed the best utilisation profile, with the pentose sugar xylose inducing the highest growth, followed by trehelose, raffinose, D-mannose turanose fructose and glucose. Among oligosaccharides, sucrose had the highest mycelium formation followed by stachyose, maltose, maltotriose, glycogen and dextrin. Interestingly the fungus also grew well on cellobiose suggesting that this fungus can produce cellulose hydrolysing proteins. D-alanine was the best amino acid to promote fungal growth while the effect of other amino acids tested was similar to the control. These results demonstrate the ability of this fungus to grow relatively well on most plant based compounds thus making this fungus a possible candidate for plant biomass conversion which can be applied to a number of biotechnological applications including biofuel production.
\end{abstract}

Keywords: Filamentous Fungi; Thermophilic; Carbon Source; Hexose; Pentose

\section{INTRODUCTION}

The importance of fungi and other microorganisms is

"Corresponding author. widely acknowledged, primarily due to their application in biotechnology industries as well as the effects they have on human health. Fungi are able to produce a variety of biotechnology products which include industrial enzymes, enzymes used in bioassays or for diagnostics, antibiotics, and enzymes involved in bioremediation $[1,2]$. During industrial application and scientific research, specific metabolic pathways or molecules that are related to a particular process are studied in depth. This however can lead to the overlooking of other molecules or useful products. The invention of genomics has produced a wealth of data, however to understand those data one must understand the relationship of genes within an organism and the interactions of gene products in metabolism.

The area of studying either gene or protein interactions on a larger scale is a relatively new field as it has spilled over from genomics. Although high-throughput screens for bacteria and unicellular fungi (yeast) using knock-out experiments are used frequently, this technique is labour intensive and time consuming. Even after obtaining mutants, methods of characterization can be limited or expensive as in the case of DNA microarrays. Alternative approaches for the characterization of functional genes are being developed and advanced [3]. One approach is to focus on the effect of a particular gene at a cellular level and to assess how it affects the organism as a whole. Therefore, phenotypic characteristics that the organism displays, become markers (for the effect) of a particular gene with relatively high certainty. Although phenotyping has been around for some time, it still provides a very useful way to describe biological differences between cells. As such, a specific phenotype is the final goal of any strain enhancement process for new products or processes. Therefore a good phenotypic assay method would be beneficiary in functional genomics [4].

Like many organisms, the natural habitat of fungi in- 
fluences what phenotype it will display. The natural environments of fungi involve many factors including, nutrients, physical factors and other organisms. The nutrients are the major contributor of phenotypic characteristics, thus assessing nutrient requirements is vital. In theory, a complete phenotyping assay will involve a combination of hundreds of carbon source, nitrogen sources, phosphate, sulphur and other nutrients. This will push the boundaries with assay numbers of hundreds of thousands when including other physical factors such as temperature, $\mathrm{pH}$ and $\mathrm{O}_{2}$. Such scales are not feasible for most laboratories due to labour and cost restrictions. The introduction of the Phenotypic MicroArray System (PM) from Biolog Incorporated (Harvard, California) offers a viable screening option for most researchers and industries. The Biolog system is designed for high throughput screening of different basic nutrient sources, additives required for growth and antagonistic compounds for numerous microorganisms including filamentous fungi. The phenotypic assays are designed from a physiological perspective to survey in vivo function of diverse pathways including both metabolic and regulatory pathways. Included in the tests are basic cellular nutritional pathways for $\mathrm{C}, \mathrm{N}, \mathrm{P}$, and $\mathrm{S}$ metabolism, $\mathrm{pH}$ growth range and regulation of $\mathrm{pH}$ control, sensitivity to $\mathrm{NaCl}$ and various other ions, and sensitivity to chemical agents that disrupt various biological pathways. The FF database also analyzes fungal growth via turbidimetric analysis (Biolog, Inc, CA). Analysis of both color development and turbidity provides for extremely accurate identifications to the species level $[5,6]$.

One of the most desired characteristics of numerous industries is the ability of an organism to utilize any plant biomass. Optimizing plant biomass conversion is a predominant factor identified for improving the production of an economical biofuel production. One of the obstacles however, is finding a suitable organism that is capable of converting different carbohydrate compounds and that has biological and physiological characteristics to be able to fit in this process. An organism that has a potential to be applied in this area is T. lanuginosus. Thus thermophilic filamentous fungus produces a wide range of thermostable enzyme including a large group of carbohydrate hydrolyses. These enzymes include: amylase, glucoamylase, xylanase, lipase, phytase, protease and chitinase [2]. These thermostable enzymes can be applied in different industries including the food industry for the production of sugar syrup, animal feed industry, pulp and paper industry and bioremediation/bio-conversion of waste industry [7]. Based on this organism's ability to produce carbohydrate hydrolases and other useful enzyme like lipases, it has been proposed that T. lanuginosus may contain previously unidentified proteins that have ability to act on the different carbohydrate material and this can be anaylsed using the Biolog system. FF MicroPlate is specifically designed for the testing of carbon utilisation in filamentous fungi and yeast, including species from the genera Aspergillus, Penicillium, Fusarium, Alternaria, Mucor, Gliocladium, Cladosporium, Paecilomyces, Stachybotrys, Trichoderma, Zygosaccharomyces, Acremonium, Beauveria, Botryosphaeria, Botrytis, Candida, and Geotrichum (Biolog, Inc.). This article discusses the use of Phenotypic MicroArray using the FF MicroPlate to assess the ability of $T$. lanuginosus to utilize different carbon sources.

\section{MATERIALS AND METHODS}

The experiments were performed by growing $T$. lanuginosus on $2 \%$ malt extract agar at $50^{\circ} \mathrm{C}$ for $5-7$ days until spore formation was visible. Global carbon assimilation profiles were evaluated by using Biolog FF MicroPlate (Biolog, Inc., Hayward, CA). The FF MicroPlate test panel contains 95 wells, each with a different carboncontaining compound, and one well with water as control. The inoculum for the 96 well FF plates for the biology system was prepared by first soaking a sterile swab then gently rolling over the plate. The spores were suspended in $16 \mathrm{ml}$ of FF inoculum media supplied by Biolog in glass tubes the mixed gently by hand. The spore suspendsion used was approximately 75\% transmittance at 590 $\mathrm{nm}$ using the Biolog Tubidometer. $100 \mu \mathrm{l}$ of the spore suspension was added to each well and microplates were incubated at $50^{\circ} \mathrm{C}$. Sample were done in triplicates and readings were taken using the Biolog Microstation, at $2 \mathrm{~h}$ intervals until $68 \mathrm{~h}$. Water and tween 80 were used as controls.

Biolog software was used to measure growth or biomass at the absorbance of $750 \mathrm{~nm}$, while assimilation (general uptake and usage) was evaluated at $490 \mathrm{~nm}$ by measuring the formation of a reddish-orange colour. Joining Cluster Analysis was used to group carbon sources utilized by $T$. lanuginosus using the Minitab 16 software (Minitab Inc.) and was applied to identify the different groups of carbon sources from the experimental data set. The joining cluster analysis was designed by means of the Euclidean distance with complete linkage. Out of the 95 compounds used in this analysis for the purpose of this study, only compound belonging to carbohydrates and amino acid groups will be discussed in details (Figure 1).

\section{RESULTS}

\subsection{Cluster Analysis of Carbon Source Assimilation and Growth Profiles}

Carbon source utilization profiles for $T$. lanuginosus were analyzed using cluster analysis. The data generated was divided into 4 distinct clusters for assimilation 


\begin{tabular}{|c|c|c|c|c|c|c|c|c|c|c|c|}
\hline A1 Water & $\begin{array}{l}\text { A2 Tween } \\
80\end{array}$ & $\begin{array}{l}\text { A3 N- } \\
\text { Acetyl-D- } \\
\text { Galactosa } \\
\text { mine }\end{array}$ & \begin{tabular}{|l|} 
A4 N- \\
Acetyl-D- \\
Glucosam \\
ine
\end{tabular} & $\begin{array}{l}\text { A5 N- } \\
\text { Acetyl-D- } \\
\text { Mannosa } \\
\text { mine }\end{array}$ & \begin{tabular}{|l} 
A6 \\
Adonitol
\end{tabular} & $\begin{array}{l}\text { A7 } \\
\text { Amygdali } \\
n\end{array}$ & $\begin{array}{l}\text { A8 D- } \\
\text { Arabinos } \\
\text { e }\end{array}$ & $\begin{array}{l}\text { A9 L- } \\
\text { Arabinos } \\
\text { e }\end{array}$ & $\begin{array}{l}\text { A10 D- } \\
\text { Arabitol }\end{array}$ & $\begin{array}{l}\text { A11 } \\
\text { Arbutin }\end{array}$ & $\begin{array}{l}\text { A12 D- } \\
\text { Cellobios } \\
\text { e }\end{array}$ \\
\hline $\begin{array}{l}\text { B1 } \alpha- \\
\text { Cyclodext } \\
\text { rin }\end{array}$ & \begin{tabular}{|l|} 
B2 $\beta-$ \\
Cyclodext \\
rin
\end{tabular} & $\begin{array}{l}\text { B3 } \\
\text { Dextrin }\end{array}$ & $\begin{array}{l}\text { B4 i- } \\
\text { Erythritol }\end{array}$ & $\begin{array}{l}\text { B5 D- } \\
\text { Fructose }\end{array}$ & $\begin{array}{l}\text { B6 L- } \\
\text { Fucose }\end{array}$ & $\begin{array}{l}\text { B7 D- } \\
\text { Galactose }\end{array}$ & \begin{tabular}{|l|} 
B8 D- \\
Galacturo \\
nic Acid
\end{tabular} & $\begin{array}{l}\text { B9 } \\
\text { Gentiobio } \\
\text { se } \\
\end{array}$ & $\begin{array}{l}\text { B10 D- } \\
\text { Gluconic } \\
\text { Acid }\end{array}$ & \begin{tabular}{|l|} 
B11 D- \\
Glucosam \\
ine
\end{tabular} & $\begin{array}{l}\text { B12 } \alpha-D- \\
\text { Glucose }\end{array}$ \\
\hline $\begin{array}{l}\text { C1 } \\
\text { Glucose- } \\
\text { 1-Phosph } \\
\text { ate }\end{array}$ & $\begin{array}{l}\text { C2 } \\
\text { Glucuron } \\
\text { amide }\end{array}$ & $\begin{array}{l}\text { C3 D- } \\
\text { Glucuroni } \\
\text { c Acid }\end{array}$ & $\begin{array}{l}\text { C4 } \\
\text { Glycerol }\end{array}$ & $\begin{array}{l}\text { C5 } \\
\text { Glycogen }\end{array}$ & $\begin{array}{l}\text { C6 m- } \\
\text { Inositol }\end{array}$ & $\begin{array}{l}\text { C7 2- } \\
\text { Keto-D- } \\
\text { Gluconic } \\
\text { Acid }\end{array}$ & $\begin{array}{l}\text { C8 a-D- } \\
\text { Lactose }\end{array}$ & $\begin{array}{l}\text { C9 } \\
\text { Lactulose }\end{array}$ & $\begin{array}{l}\text { C10 } \\
\text { Maltitol }\end{array}$ & $\begin{array}{l}\text { C11 } \\
\text { Maltose }\end{array}$ & $\begin{array}{l}\text { C12 } \\
\text { Maltotrios } \\
\text { e }\end{array}$ \\
\hline $\begin{array}{l}\text { D1 D- } \\
\text { Mannitol }\end{array}$ & $\begin{array}{l}\text { D2 D- } \\
\text { Mannose }\end{array}$ & $\begin{array}{l}\text { D3 D- } \\
\text { Melezitos } \\
\text { e }\end{array}$ & $\begin{array}{l}\text { D4 D- } \\
\text { Melibiose }\end{array}$ & $\begin{array}{l}\text { D5 } \alpha- \\
\text { Methyl-D- } \\
\text { Galactosi } \\
\text { de }\end{array}$ & \begin{tabular}{|l|} 
D6 $\beta-$ \\
Methyl-D- \\
Galactosi \\
de
\end{tabular} & $\begin{array}{l}\text { D7 a- } \\
\text { Methyl-D- } \\
\text { Glucoside }\end{array}$ & $\begin{array}{l}\text { D8 } \beta- \\
\text { Methyl-D- } \\
\text { Glucoside }\end{array}$ & $\begin{array}{l}\text { D9 } \\
\text { Palatinos } \\
\text { e }\end{array}$ & $\begin{array}{l}\text { D10 D- } \\
\text { Psicose }\end{array}$ & $\begin{array}{l}\text { D11 D- } \\
\text { Raffinose }\end{array}$ & $\begin{array}{l}\text { D12 L- } \\
\text { Rhamnos } \\
\text { e }\end{array}$ \\
\hline $\begin{array}{l}\text { E1 D- } \\
\text { Ribose }\end{array}$ & \begin{tabular}{|l} 
E2 \\
Salicin
\end{tabular} & $\begin{array}{l}\text { E3 } \\
\text { Sedohept } \\
\text { ulosan }\end{array}$ & $\begin{array}{l}\text { E4 D- } \\
\text { Sorbitol }\end{array}$ & $\begin{array}{l}\text { E5 L- } \\
\text { Sorbose }\end{array}$ & \begin{tabular}{|l|} 
E6 \\
Stachyos \\
e
\end{tabular} & $\begin{array}{l}\text { E7 } \\
\text { Sucrose }\end{array}$ & $\begin{array}{l}\text { E8 D- } \\
\text { Tagatose }\end{array}$ & $\begin{array}{l}\text { E9 D- } \\
\text { Trehalose }\end{array}$ & $\begin{array}{l}\text { E10 } \\
\text { Turanose }\end{array}$ & $\begin{array}{l}\text { E11 } \\
\text { Xylitol }\end{array}$ & $\begin{array}{l}\text { E12 D- } \\
\text { Xylose }\end{array}$ \\
\hline $\begin{array}{l}\text { F1 y- } \\
\text { Amino- } \\
\text { butyric } \\
\text { Acid }\end{array}$ & \begin{tabular}{|l} 
F2 \\
Bromosu \\
ccinic \\
Acid
\end{tabular} & $\begin{array}{l}\text { F3 } \\
\text { Fumaric } \\
\text { Acid }\end{array}$ & $\begin{array}{l}\text { F4 } \beta \text { - } \\
\text { Hydroxy- } \\
\text { butyric } \\
\text { Acid }\end{array}$ & $\begin{array}{l}\text { F5 y- } \\
\text { Hydroxy- } \\
\text { butyric } \\
\text { Acid }\end{array}$ & $\begin{array}{l}\text { F6 p- } \\
\text { Hydroxyp } \\
\text { henyl-ace } \\
\text { tic Acid }\end{array}$ & $\begin{array}{l}\text { F7 a-Keto- } \\
\text { glutaric } \\
\text { Acid }\end{array}$ & $\begin{array}{l}\text { F8 D- } \\
\text { Lactic } \\
\text { Acid } \\
\text { Methyl } \\
\text { Ester }\end{array}$ & $\begin{array}{l}\text { F9 L- } \\
\text { Lactic } \\
\text { Acid }\end{array}$ & $\begin{array}{l}\text { F10 D- } \\
\text { Malic } \\
\text { Acid }\end{array}$ & $\begin{array}{l}\text { F11 L- } \\
\text { Malic } \\
\text { Acid }\end{array}$ & $\begin{array}{l}\text { F12 } \\
\text { Quinic } \\
\text { Acid }\end{array}$ \\
\hline $\begin{array}{l}\text { G1 D- } \\
\text { Sacchari } \\
\text { c Acid }\end{array}$ & $\begin{array}{l}\text { G2 } \\
\text { Sebacic } \\
\text { Acid }\end{array}$ & $\begin{array}{l}\text { G3 } \\
\text { Succinam } \\
\text { ic Acid }\end{array}$ & $\begin{array}{l}\text { G4 } \\
\text { Succinic } \\
\text { Acid }\end{array}$ & $\begin{array}{l}\text { G5 } \\
\text { Succinic } \\
\text { Acid } \\
\text { Mono- } \\
\text { Methyl } \\
\text { Ester }\end{array}$ & $\begin{array}{l}\text { G6 N- } \\
\text { Acetly-L- } \\
\text { Glutamic } \\
\text { Acid }\end{array}$ & $\begin{array}{l}\text { G7 } \\
\text { Alaninami } \\
\text { de }\end{array}$ & $\begin{array}{l}\text { G8 L- } \\
\text { Alanine }\end{array}$ & $\begin{array}{l}\text { G9 L- } \\
\text { Alanyl- } \\
\text { Glycine }\end{array}$ & $\begin{array}{l}\text { G10 L- } \\
\text { Asparagi } \\
\text { ne }\end{array}$ & $\begin{array}{l}\text { G11 L- } \\
\text { Aspartic } \\
\text { Acid }\end{array}$ & $\begin{array}{l}\text { G12 L- } \\
\text { Glutamic } \\
\text { Acid }\end{array}$ \\
\hline $\begin{array}{l}\text { H1 Glycyl- } \\
\text { L- } \\
\text { Glutamic } \\
\text { Acid }\end{array}$ & $\begin{array}{l}\mathrm{H} 2 \mathrm{~L}- \\
\text { Ornithine }\end{array}$ & $\begin{array}{l}\mathrm{H} 3 \mathrm{~L}- \\
\text { Phenylala } \\
\text { nine }\end{array}$ & $\begin{array}{l}\text { H4 L- } \\
\text { Proline }\end{array}$ & $\begin{array}{l}\text { H5 L- } \\
\text { Pyrogluta } \\
\text { mic Acid }\end{array}$ & $\begin{array}{l}\text { H6 L- } \\
\text { Serine }\end{array}$ & $\begin{array}{l}\text { H7 L- } \\
\text { Threonine }\end{array}$ & $\begin{array}{l}\text { H8 2- } \\
\text { Amino } \\
\text { Ethanol }\end{array}$ & $\begin{array}{l}\mathrm{H} 9 \\
\text { Putrescin } \\
\text { e }\end{array}$ & $\begin{array}{l}\mathrm{H} 10 \\
\text { Adenosin } \\
\mathrm{e}\end{array}$ & $\begin{array}{l}\mathrm{H} 11 \\
\text { Uridine }\end{array}$ & \begin{tabular}{|l}
$\mathrm{H} 12$ \\
Adenosin \\
e-5'- \\
Monopho \\
sphate \\
\end{tabular} \\
\hline
\end{tabular}

Figure 1. 95 Carbon sources found in FF MicroPlate from Biolog, Inc.

(Figure 2) and for biomass (Figure 3). The analysis for general assimilation showed that cluster I and II contain carbon sources that lead to very slow biomass formation. The most dominant compounds in these clusters are amino acids, except for alanine, and organic acids, esters, alcohols, phosphorylated sugars, rare sugars, rare polymers, a nucleotide and aromatics groups. Water (control) was grouped in cluster II not I as it had higher assimilation rate. The trend was similar when growth was analyzed with exception that cluster I was bigger than cluster II (Figure 3). Amino acids and some carbohydrates are also identified to give slow formation of biomass in these clusters. The other difference was that water had moved down to cluster I while tween 80 shifted up to cluster II.

Cluster III (assimilation) showed good assimilation for T. lanuginosus. This cluster contained mainly carbohydrates which are monosaccharide (sorbose, galactose, arabinose, ribose fucose and rhaminose), disaccharides (Lactose and Lactoluse), oligosaccharides and polysaccharides (cyclodextrine, tagose, gentibiose amd meli- biose), some amino acids (asparagine and alanyl-glycine) and alcohol (sorbitol, glycerol, Maltitol and xylitol). Cluster IV contained carbon sources that enabled the fastest growth and included several monosaccharides, oligosaccharides (xylose, glucose, raffinose, glucose, fructose, cellobiose, maltose arabitol, NA-glucosamine, etc.). Growth analysis revealed that compounds found in Cluster III and IV were similar to those found in assimilation analysis cluster IV, however the cluster proportions were different. In growth analysis, most of the carbon sources clustered in group III, while only three carbon sources found in cluster IV (xylose, NAG and sucrose) which were classified as yielding higher biomass. Surprisingly, cellobiose also showed good biomass production and was clustered in group III.

\subsection{Hexoses and Pentoses}

Analysis of these 95 carbon sources was done further by analyzing carbon sources that fell into the following specific groups, hexose and pentose, oligosaccharides and 


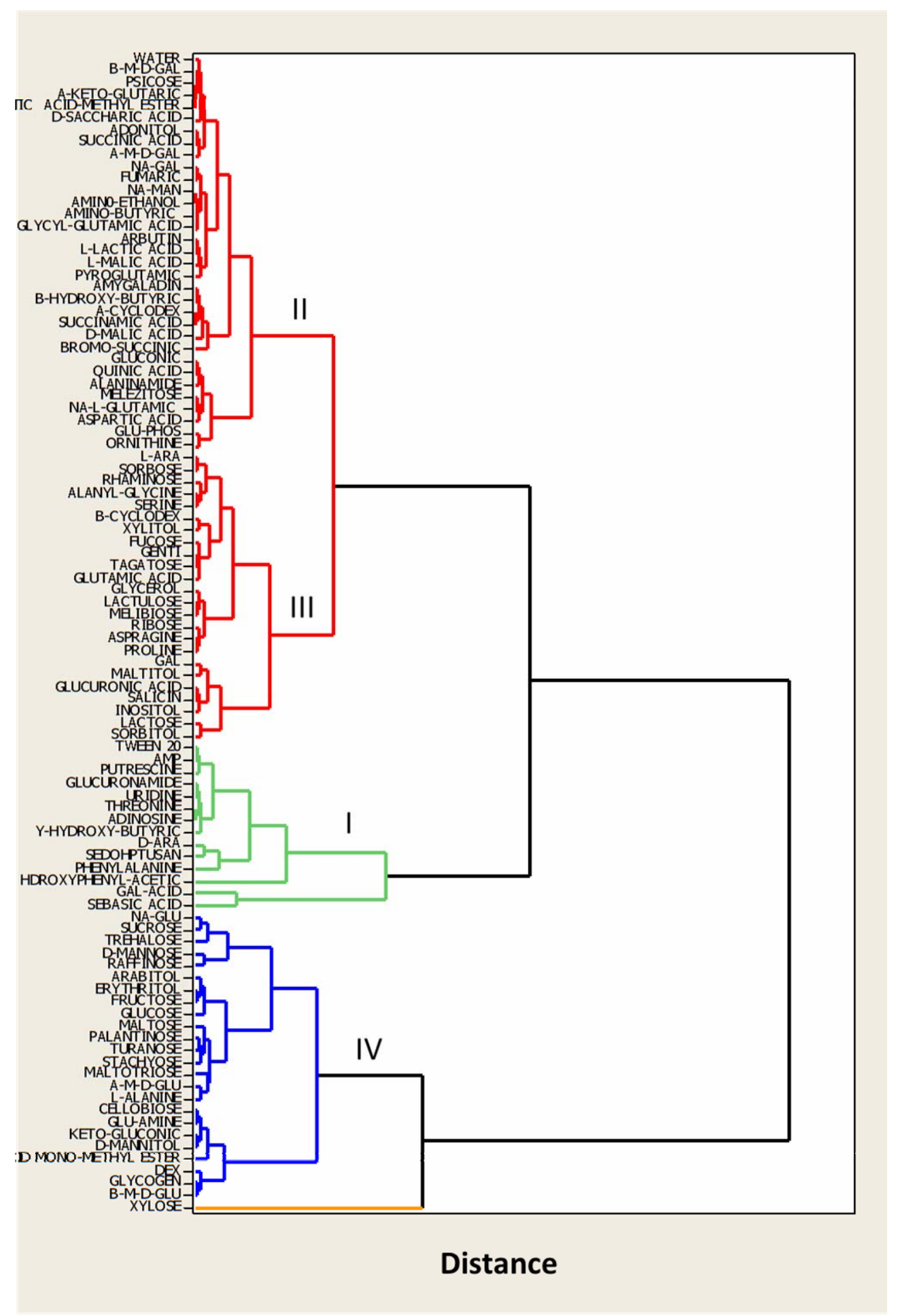

Figure 2. Joining cluster analysis applied to 95 carbon sources based on their assimilation and utilization of carbon sources by T. lanuginosus measured at $490 \mathrm{~nm}$ using the Biolog system (the standard deviation for absorbance values was an average of 0.041 ).

amino acid based compound and the rest were not assessed further. Analysis of hexose and pentose utilization revealed maximal assimilation of xylose followed by trehalose, NAG and mannose (Figures 3 and 4). Xylose exhibited $15 \%$ more assimilation than the second best compound trehalose with absorbance values of 3.1 and 2.6, repectively (Figure 4). Fructose, raffinose, glucose and turanose also showed good general assimilation. The 


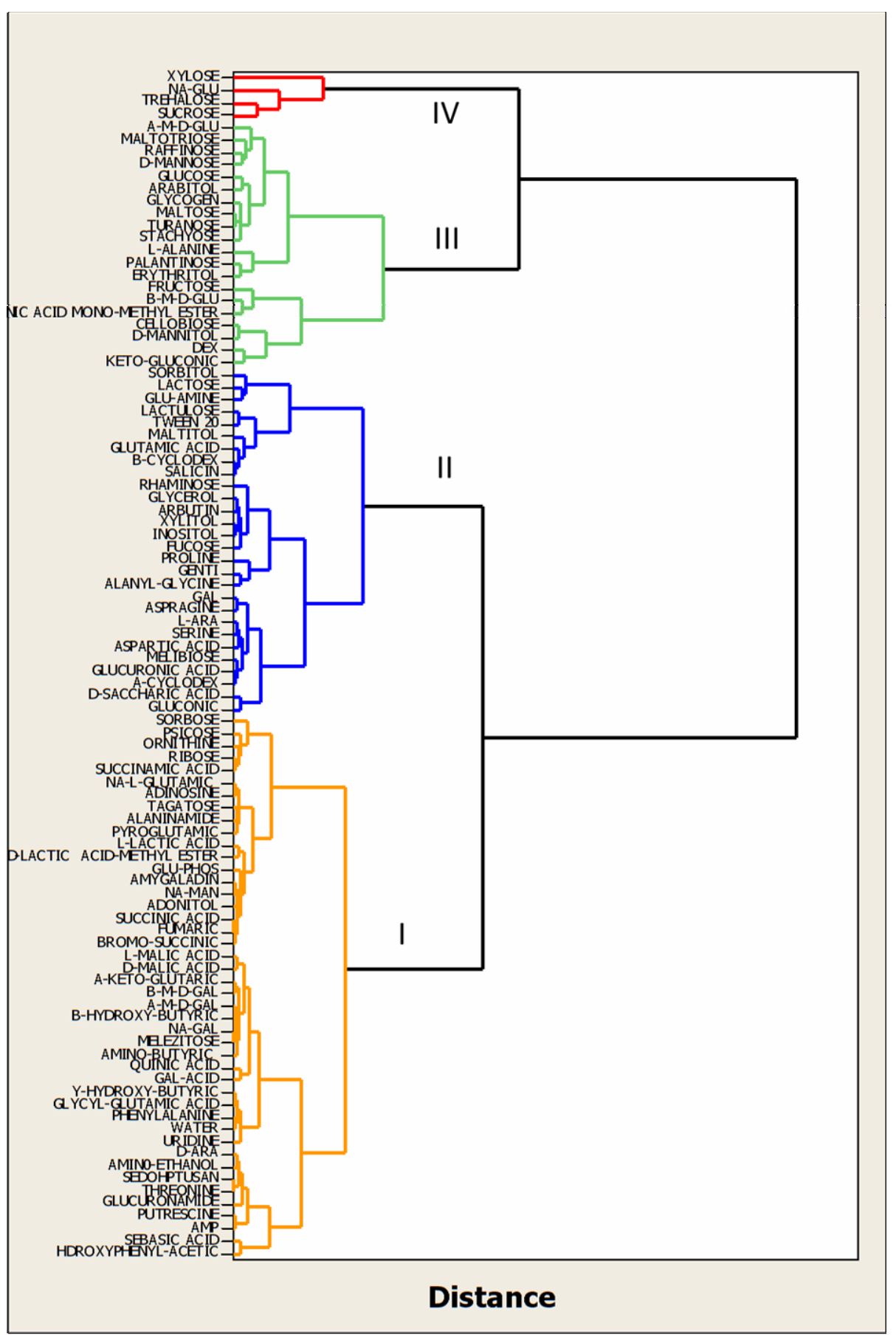

Figure 3. Joining cluster analysis applied to 95 carbon sources based on the growth of T. lanuginosus on these carbon sources. Groth was measured at $750 \mathrm{~nm}$ using the Biolog system.

biomass production showed that again xylose produced the highest biomass followed by NAG and trehalose (absorbance values, 1.4, 1.36 and 1.23, respectively, Figure 5). These were followed by glucose, mannose and raffinose with absorbance above 2 , among the better hexose and pentose sugars. Water assimilation was measured at 1.36 and for tween 80 at 1.11. Nevertheless when the effect on growth was analyzed, tween 80 showed better biomass promotion than water with absorbance of 0.68 and 0.33 , respectively.

\subsection{Oligosaccharides}

In oligosaccharide analysis, sucrose exhibited the best assimilation followed by maltotriose, stachyose, maltose, dextrin and glycogen (Figure 6). Cellobiose also showed 


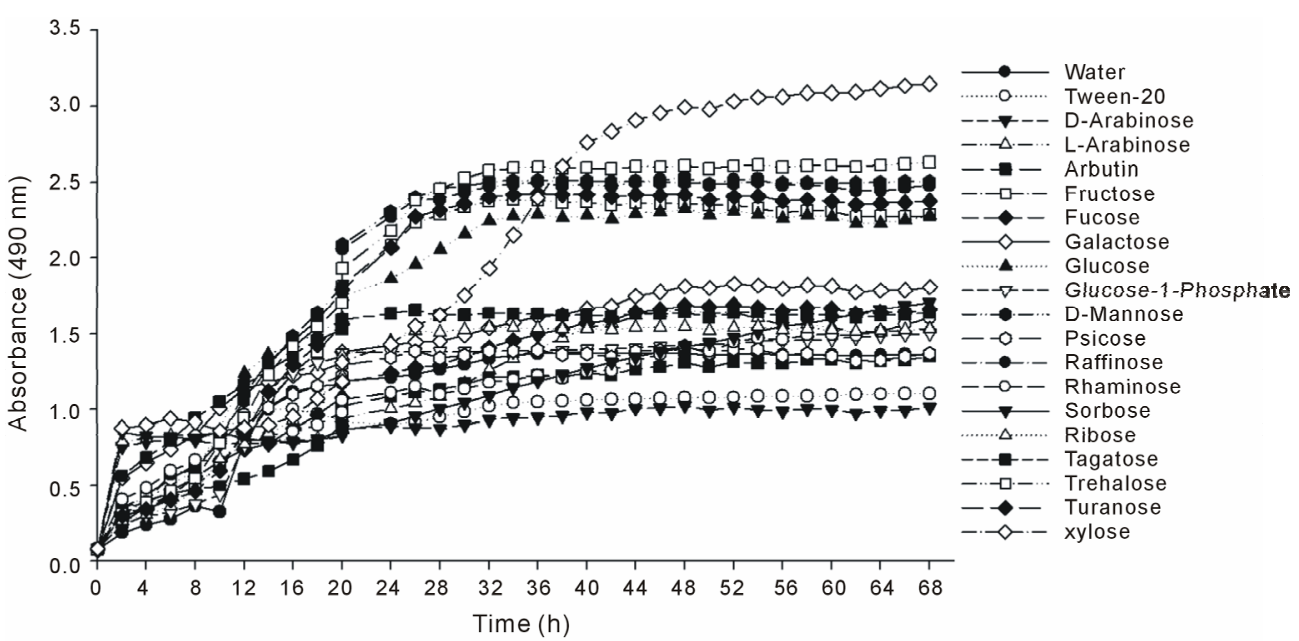

Figure 4. Assimilation of monomeric sugars (hexose and pentose) by T. lanuginosus SSBP. The assimilation was measured at an absorbance of $490 \mathrm{~nm}$ for 68 hours at 2 hour intervals.

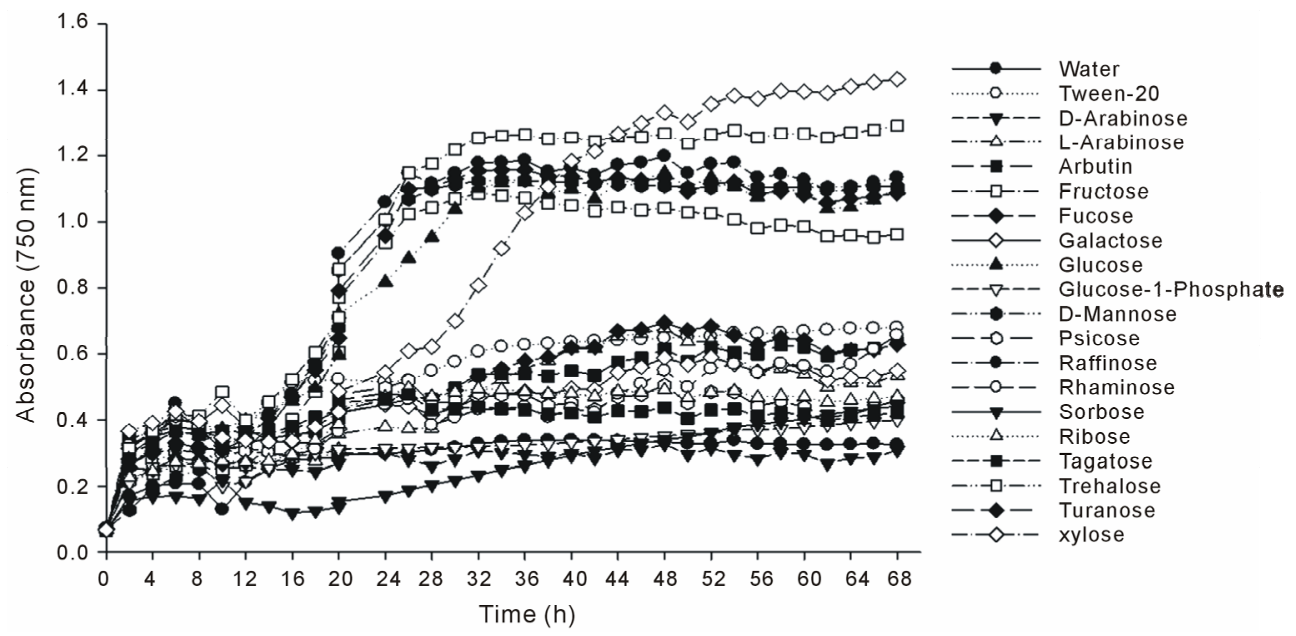

Figure 5. Growth of T. lanuginosus SSBP in monomeric sugars (hexose and pentose). The growth was measured at an absorbance of $750 \mathrm{~nm}$ for 68 hours at 2 hour intervals.

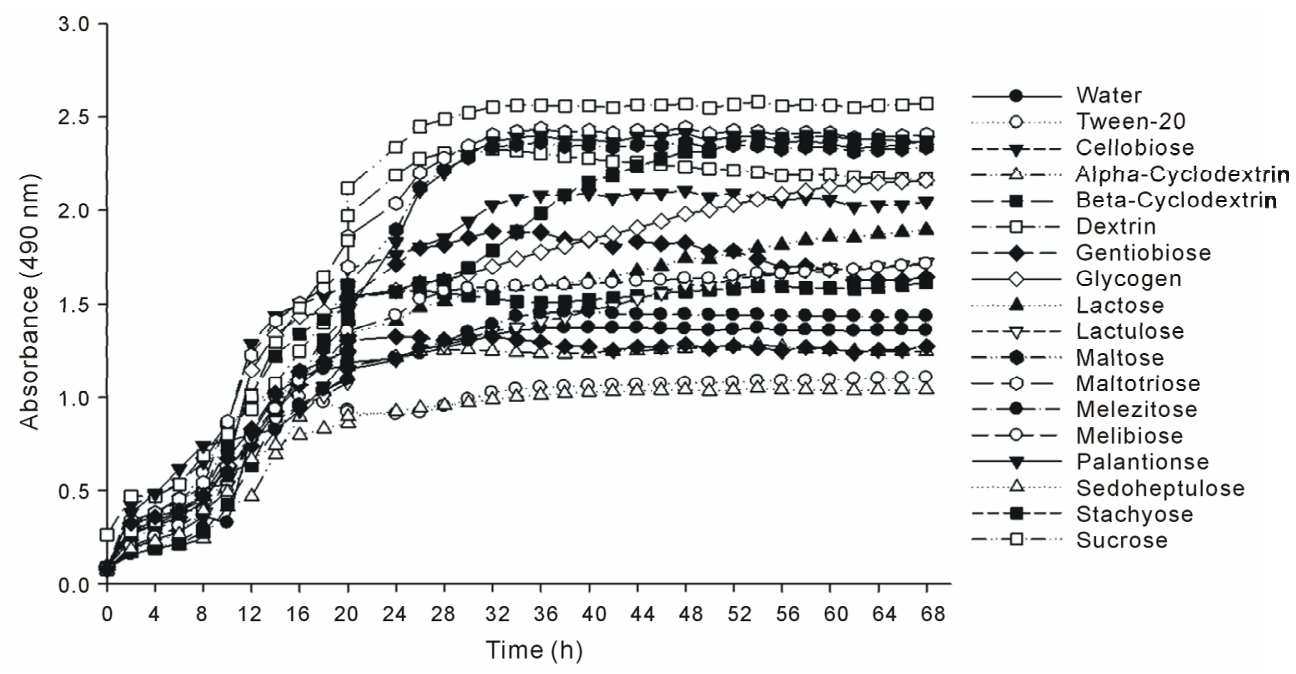

Figure 6. Assimilation of oligosaccharides by T. lanuginosus SSBP. The assimilation was measured at an absorbance of $490 \mathrm{~nm}$ for 68 hours at 2 hour intervals. 
relatively good general assimilation. Water assimilation was lower than most of common carbohydrates while the assimilation of rare occurring carbohydrate compounds was even lower than water and tween 80 (sedoheptulose and gentibiose). In biomass production sucrose again produced the most biomass followed by maltose, glycogen, maltose, stachyose, palantiose, cellobiose and dextrin (Figure 7). Again common carbohydrate compounds supported more biomass production in $T$. lanuginosus than rare compounds.

\subsection{Amino Acids}

Amino acid analysis, L-alanine displayed the best assimilation followed by proline, asparagine, and glutamic acid (Figure 8). Gylcyl-glutamic acid gave the lowest assimilation even lower than water and tween 80. It was also noted that although most of the amino acid base compounds had high assimilation, they were unable to support significant biomass production. In biomass production L-alanine yielded greater biomass when compared to other amino acids (Figure 9). The rest of the amino acid compounds produced less biomass than tween 80 but more than water except for threonine which was lower.

\section{DISCUSSION}

In nature the ability of a microorganism to use a variety of compounds is vital for survival in composting environment as different substrates are degraded and utilised by different organisms. Filamentous fungi play a vital role in this ecological dynamics as they are responsible for the majority of the hydrolysis $[8,9]$. T. lanugiosus is

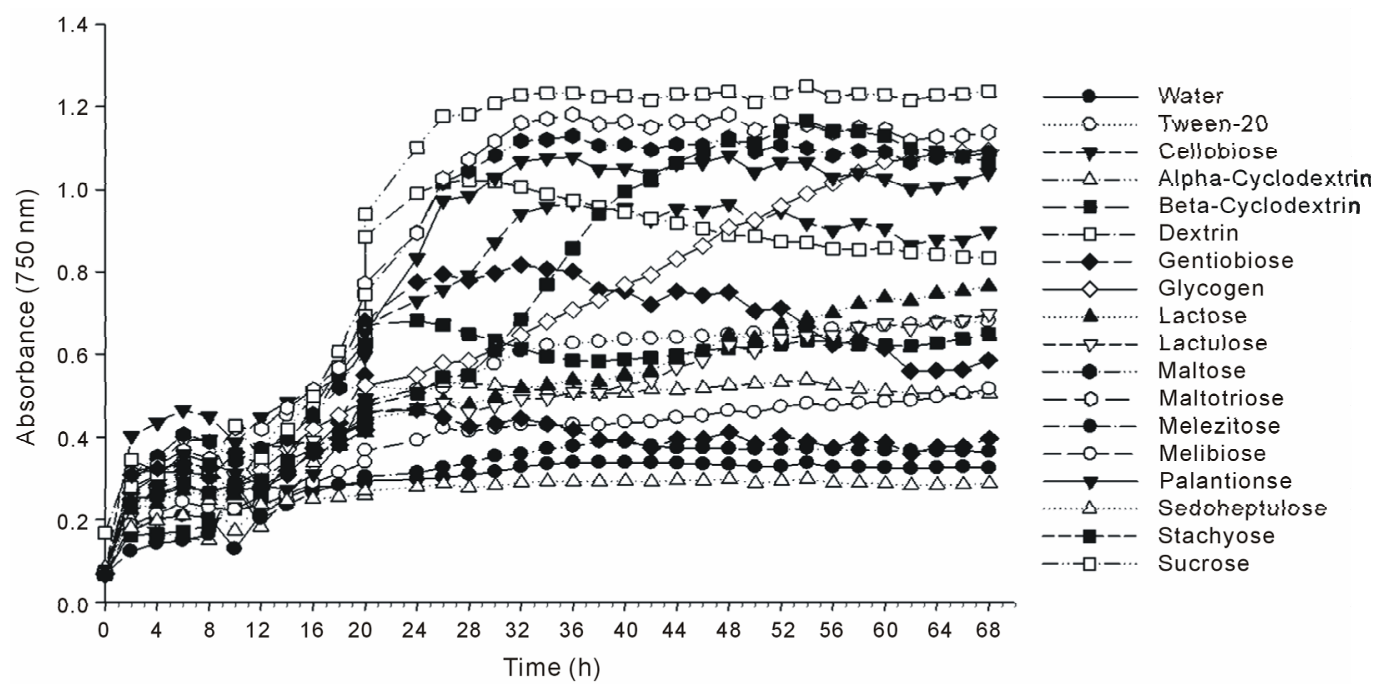

Figure 7. Growth of T. lanuginosus SSBP in oligosaccharide compounds. The growth was measured at an absorbance of $750 \mathrm{~nm}$ for 68 hours at 2 hour intervals.

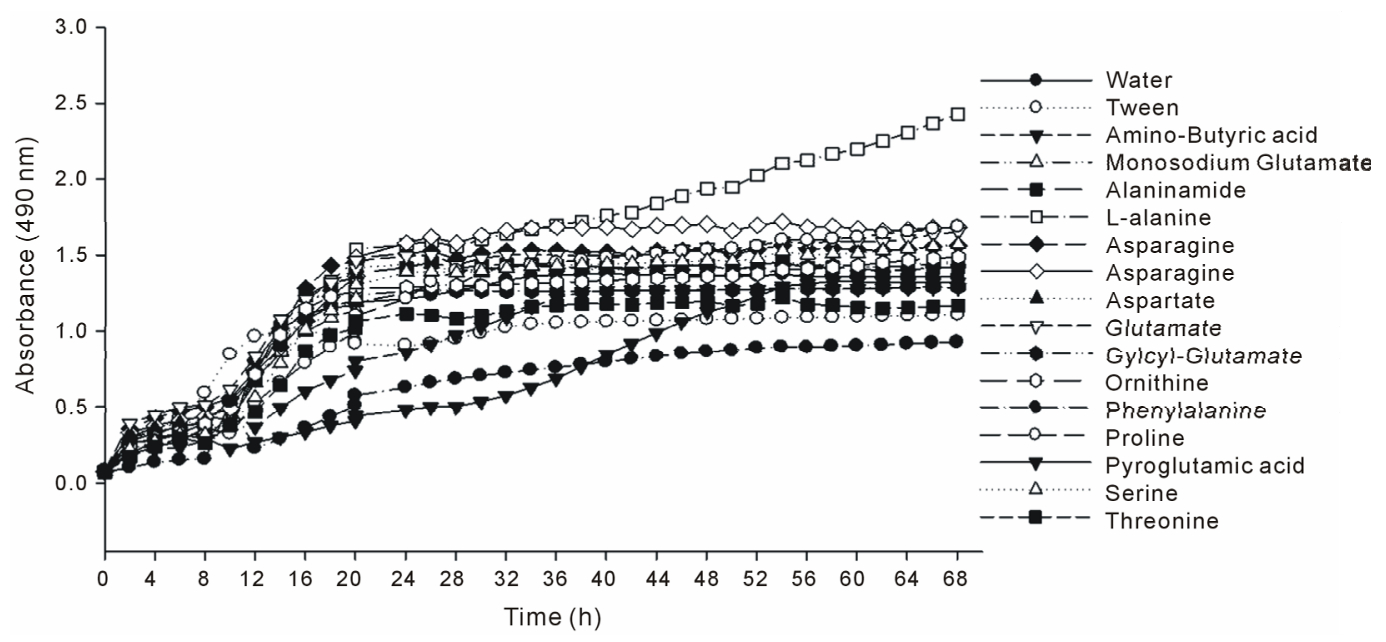

Figure 8. Assimilation of amino acid based compounds by T. lanuginosus SSBP. The assimilation was measured at an absorbance of $490 \mathrm{~nm}$ for 68 hours at 2 hour intervals. 


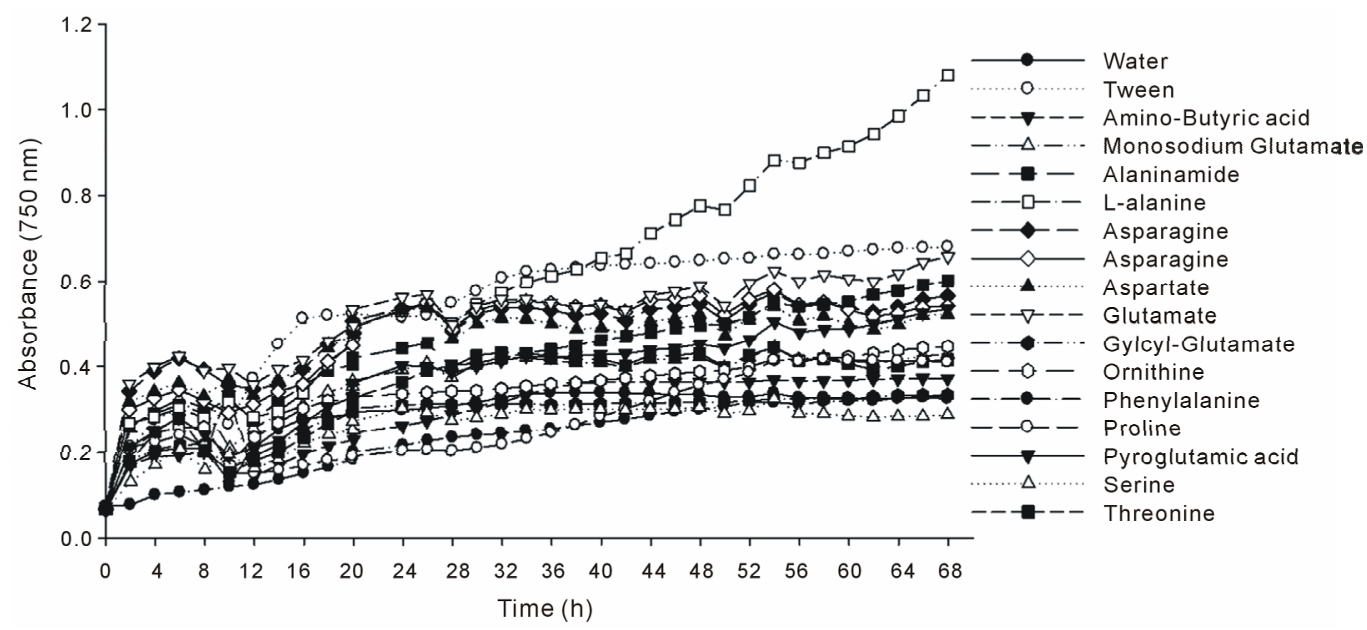

Figure 9. Growth of T. lanuginosus SSBP in amino acid based compounds. The growth was measured at an absorbance of $750 \mathrm{~nm}$ for 68 hours at 2 hour intervals.

among those fungal organisms that thrive in such environments with an added ability to survive high temperature which is only for a select few eukaryotic organisms [10]. The analysis of carbon source assimilation and utilization for biomass production in this organism revealed a similar profile to other filamentous fungi studies of this nature where glucose, xylose, trehalose and NAG produced high biomass in Trichoderma reesei and Aspergillus niger [5]. Although the clusters in these studies were similar to our findings, closer analysis of Cluster IV revealed that for T. lanuginosus, xylose is the preferred sugar compared to glucose. This concurs with reports that $T$. lanuginosus has the most powerful system for xylanase production and xylose utilization and thus it was expected that xylose would produce the most biomass and have the highest assimilation [11-13]

However, the most interesting finding was the high cellobiose utilization as this organism is well reported as a cellulose free organism. T. lanuginosus has been previously described as non-cellulolytic and it was suggested that it probably relies on commensal relationships in composts with cellulolytic fungi [13-15]. In this study, growth on cellobiose suggests that this fungus produces enzymes that have cellulose related activity. This is in agreement with unpublished data on genome sequencing of this fungus revealing that 8 predicted genes are with the possibility of having cellulose activity. Of the 8 genes, 3 were similar to Trichoderma reesei cellulases and the others to Aspergillus kawachi $[16,17]$.

Trehalose also produced good biomass and assimilation in T. lanuginosus. The suggested reason for this is that trehalose is used by the organisms as an energy source; however there is a more important reason in thermophilic organisms. Trehalose has been widely reported as a part of the physiological adaptation to various environmental stresses e.g. high temperature, in yeasts and filamentous fungi [18]. NAG also had high assimilation and biomass production because it is the building block of fungal cell walls which contain chitin and also can be converted to energy molecule, therefore high assimilation and the ability to support growth were expected [19]. It was surprising that only one amino acid, alanine, produced significant biomass. This may be because alanine is one of the few amino acids that can transform into glucose and can be used in TCA cycle to provide energy for the cell, thus it may be preferred by this fungus to supplement the supply of mineral nitrogen and energy [20].

In conclusion, this study indicates that $T$. lanuginosus is a versatile organism that can utilize a diverse range of carbon sources, including carbohydrates, amino acids, carboxylic acids, polymers, aromatics, esters, phosphorylated and sugar alcohols. The application of Phenotypic Array as a tool of carbon utilization studies is a quick approach to studying and assessing filamentous fungi for specific activities.

\section{ACKNOWLEDGEMENTS}

This study was supported by grants from the National Research Foundation, Republic of South Africa and collaboration with the Centre for Chemical Biology, University Sains Malaysia. The authors are thankful to Dr. Alison Winger, a Research Associate in Dept. Biotechnology and Food Technology Durban University of Technology, for valuable suggestions and critical evaluation of the manuscript.

\section{REFERENCES}

[1] Ghorai, S., Banik, P., Verma, D., Chowdhury, S., Mukherjee, S. and Khowala, S. (2009) Fungal biotechnology in food and feed processing. Food Research International, 42, 577-587. doi:10.1016/j.foodres.2009.02.019

[2] Singh, S., Madlala, A.M. and Prior, B.A. (2003) Ther- 
momyces lanuginosus: Properties of strains and their hemicellulases. FEMS Microbiology Reviews, 27, 3-16.

[3] Nitsche, B.M., Crabtree, J., Cerqueira, G.C., Meyer, V., Ram, A.F.J. and Wortman, J.R. (2011) New resources for functional analysis of omics data for the genus aspergillus. BMC Genomics, 12, 486.

[4] Murat, C., Riccioni, C., Belfiori, B., Cichocki, N., Labba, J., Morin, E., Tisserant, E., Paolocci, F., Rubini, A. and Martin, F. (2012) Distribution and localization of microsatellites in the perigord black truffle genome and identification of new molecular markers. Fungal Genetics and Biology, 48, 592-601. doi:10.1016/j.fgb.2010.10.007

[5] Druzhinina, I., S. , Schmoll, M., Seiboth, B. and Kubicek, C., P. (2005) Global carbon utilization profiles of wildtype, mutant, transformant strains of Hypocrea jecorina. Applied and Environmantal Microbiology, 72, 21262133.

[6] Singh, M.P. (2009) Application of biolog ff microplate for substrate utilization and metabolite profiling of closely related fungi. Journal of Microbiological Methods, 77, 102-108. doi:10.1016/j.mimet.2009.01.014

[7] Maheshwari, R., Bharadwaj, G. and Mahakingesgwara, K.B. (2000) Thermophilic fungi: Their physiology and enzymes. Microbiology and Molecular Biology Reviews, 64, 461-488. doi:10.1128/MMBR.64.3.461-488.2000

[8] Tang, J.-C. and Katayama, A. (2005) Relating quinone profile to the aerobic biodegradation in thermophilic composting processes of cattle manure with various bulking agents. World Journal of Microbiology and Biotechnology, 21, 1249-1254.

[9] Yu, H., Zeng, G., Huang, H., Xi, X., Wang, R., Huang, D., Huang, G. and Li, J. (2007) Microbial community succession and lignocellulose degradation during agricultural waste composting. Biodegradation, 18, 793-802.

[10] Puchart, V., Katapodis, P. and Biely, P. (1999) Production of xylanases, mannanases and pectinases by the themophilic Fungus Thermomyces lanuginosus. Enzyme Microbial Technology, 24, 355-361.

[11] Dodd, D., Mackie, R., I and Cann, I., K.O. (2011) Xylan degradation, a metabolic property shared by rumen and human colonic bacteroidetes. Molecular Microbiology, 79, 292-304. doi:10.1111/j.1365-2958.2010.07473.x

[12] Kuttanpillai, S.K., Ayyachamy, M., Kugen, P. and Suren, S. (2009) Production of $\beta$-xylanase by a Thermomyces lanuginosus me 134 mutant on corn cobs and its application in biobleaching of bagasse pulp. Journal of Biosci- ence and Bioengineering, 107, 494-498. doi:10.1016/j.jbiosc.2008.12.020

[13] Singh, S., Reddy, P., Haarhoff, J., Biely, P., Janse, B., Pillay, B., Pillay, D. and Prior, B.A. (2000) Relatedness of Thermomyces lanuginosus strains producing a thermostable xylanase. Journal of Biotechnology, 81, 119-128.

[14] Manimaran, A., Kuttan-Pillai, S.K., Permaul, K. and Singh, S. (2009) Hyper production of cellulase-free xylanase by Thermomyces lanuginosus ssbp on bagasse pulp and its application in biobleaching. Applied Microbiology and Biotechnology, 81, 887-893.

[15] Purkarthofer, H., Sinner, M. and Steiner, W. (1993) Cellulase-free xylanase from Thermomyces lanuginosus: Optimization of production in submerged and solid-state culture. Enzyme and Microbial Technology, 15, 677-682.

[16] Martinez, D., Cullen, D., Danchin, E.G.J., Grigoriev, I.V., Harris, P., Jackson, M., Kubicek, C.P., Han, C.S., Ho, I., Larrondo, L.F., de Leon, A.L., Berka, R.M., Magnuson, J.K., Merino, S., Misra, M., Nelson, B., Putnam, N., Robbertse, B., Salamov, A.A., Schmoll, M., Terry, A., Thayer, N., Henrissat, B., Westerholm-Parvinen, A., Schoch, C.L., Yao, J., Barabote, R., Barbote, R., Nelson, M.A., Detter, C., Bruce, D., Kuske, C.R., Xie, G., Saloheimo, M., Richardson, P., Rokhsar, D.S., Lucas, S.M., Rubin, E.M., Dunn-Coleman, N., Ward, M., Brettin, T.S., Arvas, M., Baker, S.E., Chapman, J., Chertkov, O. and Coutinho, P.M. (2008) Genome sequencing and analysis of the biomass-degrading fungus Trichoderma reesei (syn. Hypocrea jecorina). Nature Biotechnology, 26, 553-560. doi:10.1038/nbt1403

[17] Zhao, Z., Liu, H., Wang, C. and Xu, J.-R. (2013) Comparative analysis of fungal genomes reveals different plant cell wall degrading capacity in fungi. BMC Genomics, 14, 274. doi:10.1186/1471-2164-14-274

[18] Ferreira, A.S., Tótola, M.R. and Borges, A.C. (2007) Physiological implications of trehalose in the ectomycorrhizal fungus pisolithus sp. Under thermal stress. Journal of Thermal Biology, 32, 34-41. doi:10.1016/j.jtherbio.2006.08.009

[19] Hartl, L., Zach, S. and Seidl-Seiboth, V. (2012) Fungal chitinases: Diversity, mechanistic properties and biotechnological potential. Applied Microbiology and Biotechnology, 93, 533-543. doi:10.1007/s00253-011-3723-3

[20] Bechem, E.E.T. (2012) Utilisation of organic and inorganic nitrogen sources by Scleroderma sinnamariense mont. Isolated from Gnetum africanum welw. African Journal of Biotechnology, 11, 9205-9213. 